\title{
MATERIALS SUPPLY MANAGEMENT IN CONSTRUCTION PROJECTS AND SATISFACTION WITH THE QUALITY OF STRUCTURES
}

\author{
Biljana Blaževska-Stoilkovska, Tomáš Hanák, Valentina Žileska-Pančovska
}

Original scientific paper

This paper investigates how construction projects participants' evaluations of two aspects of material supply management, i.e. communication and coordination among involved parties and materials quality control, are related to satisfaction with the quality of structures. On a sample of 128 respondents in the Republic of Macedonia a questionnaire was administered to assess study variables. It was found that satisfaction with the quality of structures was relatively low. Respondents assessed materials supply management, i.e. coordination and communication among involved parties, and materials quality control as average. Pearson correlation analysis showed that these two variables as aspects of materials supply management were positively related to satisfaction with the structures' quality. A hierarchical regression analysis revealed that only perceived coordination and communication among involved parties significantly predicted participants' satisfaction with quality. It was concluded that project participants' satisfaction with the structures can be increased by paying more attention to materials supply management.

Keywords: construction project participants; materials supply management; satisfaction with quality; structure

Upravljanje nabavom materijala u građevinskim projektima i zadovoljstvo kvalitetom konstrukcija

Izvorni znanstveni članak

U radu se ispituje kako su procjene sudionika građevinskih projekata o dva aspekta upravljanja nabavom materijala, t.j. komunikaciji i koordinaciji između uključenih strana i kontroli kvalitete materijala, povezane sa zadovoljstvom kvalitetom konstrukcija. Na uzorku od 128 ispitanika iz Republike Makedonije provedeno je ispitivanje o procjeni datih varijabli. Ustanovljeno je da je zadovoljstvo kvalitetom konstrukcija relativno malo. Ispitanici su kao prosječno ocijenili upravljanje nabavom materijala, t.j. koordinaciju i komunikaciju između uključenih strana i upravljanje kvalitetom materijala. Analiza korelacije po Pearsonu pokazala je da su te dvije varijable, kao aspekti upravljanja nabavom materijala, pozitivno povezane sa zadovoljstvom kvalitetom konstrukcija. Hijerarhijska analiza regresije je pokazala da je samo uočena koordinacija i komunikacija između uključenih strana značajno ukazivala na njihovo zadovoljstvo kvalitetom. Zaključeno je da se zadovoljstvo sudionika projekta konstrukcijom može povećati ako se više pažnje posveti upravljanju nabavom materijala.

Ključne riječi: konstrukcija; sudionici građevinskog projekta; upravljanje nabavom materijala ; zadovoljstvo kvalitetom

\section{Introduction}

The services provided within the construction industry include design, project management, building control and quantity surveying, which lead to varying degrees of satisfaction for the project participants and for customers. Service quality in construction must be managed in order to match changing customer expectations over time [1]. Generally, clients expect that the structure will be completed within the agreed time, cost and quality targets, as applied for both the construction project management and the contracting services [2].

Nowadays technological changes directly affect the construction sector. Construction projects are becoming more complicated and depend on many factors. Therefore, it is increasingly difficult to complete the projects with the right materials and within the quality standards, limited budget costs and on time. The supply of materials may be delayed, the quality of structures may suffer and project participants' expectations and satisfaction with the work done may be unfulfilled. In these conditions, an appropriate management system for building materials management will lead to benefits for construction [3].

The materials issues within structures construction are included in the Construction Law of the Republic of Macedonia. This law prescribes compulsory use of quality materials and providing a proof of quality of the construction products used [4]. More specifically, the use of quality products is one of the necessary prerequisites for ensuring compliance with the basic requirements for the whole structure: mechanical durability and stability, fire protection, they must comply with the sanitary, health and environment protection, they must be safe for use, noise protected, energy saving and heat insulated [4].

Taking all this into consideration, in this paper the aggregated opinion of a broad range of construction project participants (contractors, designers, developers, supervisors, material suppliers, material dealers, storage assistants, and material sellers) about communication and coordination among parties in construction process and materials quality control as two aspects of materials supply management, as well as their satisfaction with the quality of structures (buildings, non-buildings structures and facilities) were examined.

The paper is structured as follows: firstly, the literature review on supply chain management, satisfaction concept and material management in construction project is carried out. Consequently, the aim of the study is presented and research methodology described. Then, obtained results are presented and discussed. The final part of the paper comprehends study limitations and conclusions.

\subsection{Literature review}

Companies are faced with increasing competition in the market, and therefore it is necessary to pay due attention to performance measurement and maintaining or strengthening their competitiveness. One of the approaches that support enhancing overall organizational 
competitiveness is Supply Chain Management (SCM), an operations paradigm that is increasingly applied [5]. A supply chain is defined as a network of organizations that are involved in different processes and activities that produce value in the form of products and services in the hands of end customers (Christopher, 1992, as cited in [6]). According to a more recent, yet similar definition, a supply chain is defined as a very complex process of planning, implementing, and controlling an efficient and effective flow of goods, services and specific information from the point of origin to the point of consumption so as to achieve compliance with the customer's requirements (Schileru, 2008, as cited in [7]).

\subsubsection{Supply chain management as a management strategy in the construction sector}

Because of its success in other industries, SCM has also been incorporated in the construction sector. Considerable conceptual similarities between manufacturing and construction materials management have been discovered, e.g. in terms of objectives, inputs or major activities. But, it is necessary to take into consideration the character of the respective environment in which the specific processes are carried out, because there are significant differences in the homogeneity and standardization of materials [8]. The above-mentioned circumstances imply that construction has been relatively slow to adopt SCM as a management strategy, in particular due to the unique context in which SCM collaboration must be applied [9].

In the construction industry, the supply chain refers to the flow of materials, information, services, products and funds between clients, designers, contractors and suppliers, whereas the construction supply chain management is an integration of all of the construction processes, from clients' demands, design and construction to all of the participants in the construction supply chain (client, designer, contractor, subcontractor, supplier) [10]. All construction processes are carried out within the framework of the given construction project, typically characterized by a high number of stakeholders, involving the client, designer, contractor, subcontractors, suppliers, consultant and competent authorities. This makes the project a multi-organisational process [10] in which fundamental construction operations of facilities, inventory control and communication planning need to be closely coordinated [11]. The complexity of the construction process is asserted in [10] since the activities on the construction site are generally accompanied with cost and time overruns, high fragmentation, low productivity and conflicts and disputes compared with other manufacturing industries. From this perspective, indepth analysis of overruns is desirable since they are caused by a large number of factors [12]. As a result of inaccurate information transfer and wrong deliveries in the construction supply chain, unsatisfactory performance has been recorded in [10].

Unlike manufacturing production, construction output is an activity of an investment nature, where selected materials, dimensions, delivery date or project duration are essential aspects for the customer [9].
In the context of the UK construction industry it has been found that the most important factors considered when forming a supply chain relationship from the contractor's point of view are the quality of the service and cost benefits derived from a supplier [9]. The results of the study also showed that contractors are more oriented towards clients rather than suppliers in the supply chain.

In the contemporary context of market relations, especially regarding compliance with quality regulations in construction, the emphasis should be placed on the responsible chain management. This concept refers to the improvement of the relations among suppliers and compliance in product quality between the services provided and the expectations of the customer [7]. According to [7], Macedonia together with Bosnia and Herzegovina and Serbia is ranked among the lowest of emerging European countries based on the performance of responsible supply chain management, while Estonia, the Czech Republic and Slovakia are at the top of the list.

\subsubsection{The satisfaction concept in supply management}

The function of the construction industry is to provide customers with facilities that meet their needs and expectations [11]. Clients' utmost expectation is to receive the completed building within the agreed time, cost and quality targets [2], thus operational quality at each stage in the construction process should ensure that the quality of the final product will satisfy the ultimate customer [11]. A number of studies have demonstrated that the supply side still has deficiencies in this field. For example, in property markets, the supply side fails to meet the building information needs of the demand side about the quality, performance and service provided by a facility, as indicated in [13]. In another study [14], an analysis of customer satisfaction and quality in construction was conducted. The results emphasized the need for contractors to improve performance in quality assurance, handover procedures and materials.

Satisfaction is considered to be one of the main challenges in the construction industry [15]. Satisfaction in construction refers to the match between the stakeholders'/clients' pre-project expectations and the actual performance of each project stage [16]. Accordingly, it could be stated that an important role for satisfaction in construction is also played by the building materials supply stage.

It is also worth noting that the type of construction project may affect the degree of participants' satisfaction. Research presented in [17] showed that performance of infrastructure projects has been evaluated at a lower level than other project types in light of the project participants' satisfaction. This study highlighted the fact that infrastructure projects are unique and different from residential projects, thus a corresponding reproduction of the skills or repetition does not occur.

The assessment of satisfaction is a difficult and complex issue. Authors in [2] argue that many researchers consider satisfaction as an overall summary measure, while others indicate that satisfaction should be measured by a combination of facets or attributes. Thus, there is no generally accepted concept of how to measure 
satisfaction. Four basic model types that can be utilised for the determination of customer satisfaction levels are presented in [1]. Another study [15] introduces a conceptual framework for satisfaction assessment in the construction sector with the set of satisfaction attributes classified into four categories focused on cost, quality, time and safety and environment.

The level of satisfaction is partially subjective, since it is a function of perceived quality and disconfirmation the extent to which perceived quality fails to match repurchase expectations. In this context, an extensive difference between the loyalty of merely satisfied customers and those who are completely satisfied is stressed, since "merely satisfied" customers tend to switch suppliers [14]. Taking all this into account, the assessment of satisfaction with the quality of structures is in great demand.

Finally, it could be concluded that studies of clients' satisfaction with facilities' quality are well documented, but there is a lack of evidence about construction project participants' (contractors, designers, developers, supervisors, material suppliers, material dealers, storage assistants, and material sellers) satisfaction with quality of structures built.

\subsubsection{Significance of material management in a construction project}

Many studies have revealed that effective management of construction materials plays a significant role in the performance of construction projects (e.g. [18]; [19]). Authors in [20] state that in the process of the flow of materials from suppliers to construction sites, the focus should be on coordination and communication between project participants. The results of a research of UK contractors' opinions on supply chain collaboration and management demonstrated that these factors are important for construction projects, but that the level of integration in the construction process is low [9]. It is necessary to understand the requirements of every participant involved in the project, therefore all the aspects of materials supply management should be coordinated and communicated in order to attain satisfaction for both the customers and the construction company [11]. For [21], the prime contractor is responsible for the coordination of materials supply management so that high-quality projects are delivered on time and within the constrained budget.

The aspect of material is emphasized also in [3], because the success of the construction process depends not just on having the right people that are able to finish the project on time and within budget, but also on having the right materials in the right place and at the right time. Similarly, as concluded in [11], material flow and information flow are worthy of greater attention. This study also stresses the need to explore the relationship between material suppliers and contractors from the perspective of understanding satisfaction [11].

Building construction and operation are considered to be one of major consumers of material [22].Therefore, it is of particular interest to minimize handling of construction materials, which reduces costs and the chances of damage or misplacement [11], and to provide transparency of material availability and prompt responses in the supply chain [18]. A construction company must foresee usual problems in construction materials management, because poor materials management is a major source of low construction productivity, cost and time overruns [23] and it may lead to economic penalties [18].

\subsection{The aim of the present study}

The review of the literature presented in the previous chapter indicates that the assessment of satisfaction with the quality of structures is in a great demand. In addition, it is obvious that the quality of structures significantly depends on the materials used and the management of their supply to the construction site. In this study emphasis was put on two aspects of building materials supply management - communication and coordination among projects' participants and materials quality control. Broader number of different stakeholders takes part in construction process with particular roles and duties. Although their goals are often conflicting, their activities are interrelated. Thus, open communication among them and well coordinated actions/operations are very important for information flow, on time deliveries and working with high performance. On the other hand, quality of delivered materials should be adequately addressed. As could be proposed, this might lead to satisfaction among stakeholders with the work performed, i.e. with the quality of structures. Quality in this study is understood as a level at which structures fulfil/meet the end-users' needs. Satisfaction is considered as an indicator of needs and requirements fulfilment of construction projects participants/stakeholders and their reaction toward work/project performed.

Therefore, the aim of this study was to examine:

1. Construction project participants' opinion about materials supply management, i.e.: a) coordination and communication among parties involved in the project, and b) materials quality control,

2. Project participants' satisfaction with the quality of the structures.

More precisely, the focus of this research was to explore how construction projects participants' evaluations of material supply management, i.e. communication and coordination among involved parties and materials quality control are related to their satisfaction with the quality of structures.

Accordingly, the following hypotheses were defined:

$\mathrm{H} 1$ : Communication and coordination in materials supply process is positively related to construction project participants' satisfaction with the quality of structures.

$\mathrm{H} 2$ : Quality control in materials supply process is positively related to construction project participants' satisfaction with the quality of structures.

\section{Research methodology}

\subsection{Sample and procedure}

The sample consisted of 129 experienced participants in construction projects in the Republic of Macedonia. In order to describe sample structure, the following 
information is presented: 29 respondents were contractors, 22 were designers, 22 were developers, 15 were supervisors, 17 respondents were material suppliers, 7 were dealers, 17 were categorized as others (i.e. storage assistants, material sellers) and only 1 respondent was a producer of construction materials. According to their educational level, 4 respondents had only primary education, 51 had completed secondary school, 73 had a university diploma and 1 participant did not report his/her educational degree. Thirteen respondents had less than one year tenure, 23 had a tenure of between one and five years, 33 subjects had six to ten years of tenure, 58 had more than ten years of tenure, and 1 participant did not report his/her tenure.

The data were collected from October to December, 2013, during working breaks. It was explained to respondents that participation is voluntary and that responses will remain confidential and only used for research purposes. The questionnaire was filled out in approximately 15 minutes.

\subsection{Measures}

The data were obtained using a questionnaire developed exclusively for the purposes of this study. A set of statements was divided into three sections as explained below.

The first section consisted of 10 statements. Of these, 4 statements asked about the coordination and communication among involved parties in a material supply chain (e.g. Activities at construction site and materials supply are well coordinated).

Other 6 questions measured the quality control of the delivered materials on the construction site (e.g. Delivered building materials have a quality certificate). Respondents gave their answers/opinions about coordination and communication, as well as about materials' quality control during supply process on a 5point Likert scale (from 1 - completely disagree to 5completely agree). Namely, they had to choose one point from 1 to 5 for each statement in regard to their level of agreement with that statement.

Higher obtained score in the first section of the questionnaire denoted higher degree of assessed coordination and communication in the supply process. Higher obtained score in the second section of the used questionnaire refers to evaluation of materials quality control at a higher level, as well. The Cronbach alpha reliability of the scale was .70 .

Second part of the questionnaire was represented by a single-item measure used to assess project participants' satisfaction with the quality of the structures (the question was defined as follows: Indicate to what degree, in general, you are satisfied with the quality of the structure built). The answers were rated on a scale from 1 (completely dissatisfied) to 5 (completely satisfied). A higher score indicated a higher degree of satisfaction with the quality of structures. This general approach in measuring satisfaction in construction is used by many authors, as it is mentioned above.

The third section contained questions on demographic characteristics (gender, education, tenure and role in the construction project) in order to obtain information about sample structure. Data in the third section were used just to verify the suitability of respondents, thus they are not statistically evaluated in the study.

\subsection{Data analysis}

Firstly, the linear correlation method (Pearson coefficient) was employed for testing the hypotheses.

Secondly, hierarchical linear regression was conducted in order to analyse the contribution of assessed quality control and coordination and communication as aspects of materials supply management in predicting the construction project participants' satisfaction with the quality of structures. Accordingly, perceived materials quality control and perceived coordination and communication were employed as predictors, while satisfaction with the quality of structures was a criterion variable.

In the first step, quality control variable was entered, while coordination and communication variable was entered in the second step. It was proposed that the first variable is a better predictor of satisfaction with the quality of structures than the second variable.

Assumptions for applying the regression model were checked. The results (collinearity and residuals analyses) indicated that they were met.

\section{Results}

Means, standard deviations and zero-order correlations between research variables are presented in Tab. 1. As can be seen, the mean of the coordination and communication aspect of materials supply management $(M=3,00 ; S D=0,55)$ and the mean of the materials quality control $(M=3,04 ; S D=0,62)$ were equal to the midpoint of the measurement scales (ranging from 1 to 5). This implies that respondents assessed coordination and communication among the parties in the supply of construction materials as well as the quality control of the received materials to a moderate extent. The mean of satisfaction with the quality of structures $(M=2,67$; $S D=0,90$ ) was lower than the midpoint of the scale (from 1 to 5). It can be concluded that the surveyed participants in the construction projects were below-average satisfied by the quality of the structures.

Pearson's correlation coefficients demonstrated that the variables studied were positively and significantly correlated with each other. More precisely, when coordination and communication as an aspect of materials supply management is evaluated as better and when materials quality control is assessed at a higher level, then expressed satisfaction with the quality of structures is stronger.

Table 1 Means, standard deviations and correlation coefficients (Pearson) between study variables $(N=129)$

\begin{tabular}{|l|c|c|c|}
\hline \multicolumn{1}{|c|}{ Research variables } & 1 & 2 & 3 \\
\hline Coordination and communication & - & $0,444^{* *}$ & $0,424^{* *}$ \\
\hline Materials quality control & - & - & $0,230^{* *}$ \\
\hline Satisfaction with structures' quality & - & - & - \\
\hline$M$ & 3,00 & 3,04 & 2.67 \\
\hline$S D$ & 0,55 & 0,62 & 0,90 \\
\hline
\end{tabular}


Accordingly, Hypothesis 1 and Hypothesis 2 were confirmed.

It was evident that coordination and communication among involved parties in the supply of construction materials is strongly related to satisfaction with the quality of structures, rather than with the materials quality control.

The results of hierarchical linear regression analysis standardized Beta coefficients, coefficient of multiple correlation $(R)$ and coefficient of determination $\left(R^{2}\right)$ are reported in Tab. 2. They showed that materials quality control as an aspect of materials supply management accounted for 5,9\% of the variance in satisfaction with the quality of structures $(F(1 ; 127)=7,06 ; p<0,001)$. Model 1 revealed that the respondents who rated highly materials supply management from the viewpoint of observing the appropriate quality of the materials and having the necessary attestations and quality certificates were more satisfied with the quality of structures in general $(\beta=0,23 ; p<0,01)$. When coordination and communication aspect of the materials supply management was entered into the regression model (Model 2), the contribution of the materials quality control variable in the prediction of the criterion variable was not significant $(\beta=0,052 ; p>0,05)$. The coordination and communication variable explained a significant $13 \%$ in the variance of satisfaction with the quality of structures $(F(1 ; 126)=19,84 ; p<0,001)$. The correlation between these two variables was positive and strong $(\beta=0,40 ; p<0,001)$, i.e. an estimation that coordination and communication between all parties involved in the materials supply process is high leads to higher satisfaction with the quality of structures.

Table 2 Hierarchical regression analysis results: criterion variable satisfaction with the quality of structures

\begin{tabular}{|c|c|c|}
\hline Predictors & Model 1 & Model 2 \\
\hline $\begin{array}{l}\text { Step 1: Perceived materials } \\
\text { quality control }\end{array}$ & $0,23^{* *}$ & \\
\hline $\begin{array}{l}\text { Step 2: Perceived materials } \\
\text { quality control }\end{array}$ & & 0,05 \\
\hline $\begin{array}{l}\text { Perceived coordination and } \\
\text { communication }\end{array}$ & & $0,40^{* * *}$ \\
\hline$R$ & 0,23 & 0,47 \\
\hline$R^{2}$ & 0,053 & 0,18 \\
\hline$R_{\text {change }}^{2}$ & 0,053 & 0,13 \\
\hline$F_{\text {change }}$ & $7,06^{* *}$ & $19,84^{* * *}$ \\
\hline
\end{tabular}

$* *$ significant at level .01***significant at level .001

\section{Discussion}

The processes of materials supply management and structures construction are fraught with many difficulties and problems which have a strong effect on the duration of construction projects and on project participants' satisfaction with the quality of structures. For example, one of the problems arises from the suppliers: breach of the agreed delivery time, quantity or quality, incorrect documentation of the delivery, incorrect packaging and damage to the packaging or delivery product [24]. As suggested in [20], through coordination and communication, material suppliers and recipients must specify details regarding transportation, site location, order of delivery, size of packaging and all these pieces of information should be available to all parties involved. For [14], the need for contractors to improve performance relates mostly to quality assurance, handover procedures and material.

In this paper, the focus was on two aspects of materials supply management in construction: a) coordination and communication and b) materials quality control from the perspective of participants in construction projects. Their satisfaction with the quality of the structures was examined as well.

The research findings indicated that construction project participants were partially satisfied with the quality of the structures in the Republic of Macedonia. As for materials supply management, respondents stated that cooperation and communication among parties in the supply of construction materials is at an average level. They assessed the quality control of the received materials to be at a moderate extent.

It was found that when both of the aspects of materials supply management studied were assessed more positively, construction project participants' satisfaction with the quality of the structures was higher. However, when taken together, only coordination and communication significantly predicted satisfaction with the quality of structures. These results could be seen as an extension of findings presented in [25].

According to the above-mentioned, if all phases of the materials supply are not sufficiently coordinated and if communication among parties is not at a satisfactory level as well, many risks can arise. These risks include delivery of incorrect materials and deliveries not being made on time. Finally, satisfaction of the project participants with the quality of structures will be low. Namely, satisfaction as one of the key challenges in the construction sector [15] should be considered together with coordination and communication during the process of supplying materials.

Therefore, this research highlighted the need for integration of different aspects of materials supply management during the structures construction in order to increase the project participants' satisfaction with the quality of structures and consequently, to improve the performance of construction projects. In that way, the practices of top-rated countries in this domain (e.g. the Czech Republic) should be used as a model. Open and well-established communication and coordination among the participants is a good way to overcome the gap between different parties and achieve the overall goals of the project [3].

For that reason, the management of construction firms and the policy-makers should pay more attention and effort to create the conditions for an adequate materials supply process and to help ensure timely completion and quality assurance of projects. In that way, implementation of ICT should be seen as one of the important factors in strengthening the material supply process in construction (e.g. [26, 27]).

\section{Limitations of the study}

This study has a few limitations. Firstly, self-reported measures were used which may bring altered and biased responses. The second limitation is the one-item assessment of satisfaction with the quality of structures. 
Additionally, its cross-sectional design does not permit one to conclude that a causal relationship exists between the investigated variables.

\section{Conclusion}

Notwithstanding the limitations, the research conducted has contributed to the extension of literature on materials supply management and quality of structures from the perspective of construction project participants (contractors, designers, developers, supervisors, material suppliers, material dealers, storage assistants, and material sellers). Accordingly, it could be concluded that project participants' satisfaction with the structures that are built can be increased by paying more attention to management of the supply of building materials.

The results of this study serve as a basis for carrying out more detailed research and analysis in the abovementioned areas of construction in order to detect the sources of project participants' satisfaction with the quality of structures, and thus with the work done.

\section{References}

[1] Gunning, J. G. Models of customer satisfaction and service quality as research instruments in construction management. // Proceedings of the 16th Annual ARCOM Conference, Glasgow, UK, 2000, pp. 21-30.

[2] Mbachu, J.; Nkado, R. Conceptual framework for assessment of client needs and satisfaction in the building development process. // Construction Management and Economics. 24, 1(2006), pp. 31-44. DOI: 10.1080/01446190500126866

[3] Donyavi, S.; Flanagan, R. The impact of effective material management on construction site performance for small and medium sized construction enterprises. // Proceedings of the 25th Annual ARCOM Conference, Nottingham, UK, 2009, pp. 11-20.

[4] The Official Gazette of R. of Macedonia, no. 70/2013, Law on Construction (in Macedonian). 2013. URL: http://www.pravo.org.mk/documentDetail.php?id=4694 (7.12.2013)

[5] Magalhães-Mendes, J.; Rodrigues, M. F.; Ferreira, L. M. Construction supply chain management: a Portuguese Case Study. // Proceedings of the 3rd European Conference of Civil Engineering Recent Advances in Engineering, Paris, France, 2012, pp. 116-121.

[6] Vrijhoef, R.; Koskela, L. The four roles of supply chain management in construction. // European Journal of Purchasing and Supply Management. 6, 3-4(2000), pp. 169178

[7] Ganescu, M. C.; Asandei, M.; Gangone, A.; Chirilă, C. Performance determinants for responsible supply chain management in the European emerging countries. // Amfiteatru Economic. 15, 33(2013), pp. 154-169.

[8] Ibn-Homaid, N. T. A comparative evaluation of construction and manufacturing materials management. // International Journal of Project Management. 20, 4(2002), pp. 263-270. DOI: 10.1016/S0263-7863(01)00013-8

[9] Akintoye, A.; McIntosh, G.; Fitzgerald, E. A survey of supply chain collaboration and management in the UK construction industry. // European Journal of Purchasing \& Supply Management. 6, 3-4(2000), pp. 159-168.

[10] Xue, X.; Wang, Y.; Shen, Q.; Yu, X. Coordination mechanisms for construction supply chain management in the Internet environment. // International Journal of Project
Management. 25, 2(2007), pp. 150-157. DOl: 10.1016/j.jproman.2006.09.006

[11] Jang, H.; Russell, J. S.; Yi, J. S. A project manager's level of satisfaction in construction logistics. // Canadian Journal of Civil Engineering. 30, 6(2003), pp. 1133-1142. DOI: 10.1139/103-068

[12] Memon, A. H.; Rahman, I. A. Analysis of cost overrun factors for small scale construction projects in Malaysia using PLS-SEM method. // Modern Applied Science. 7, 8(2013), pp. 78-88. DOI: 10.5539/mas.v7n8p78

[13] Lützkendorf, T.; Speer, M. T. Alleviating asymmetric information in property markets: building performance and product quality as signals for consumers. // Building Research \& Information. 33, 2(2005), pp. 182-195. DOI: $10.1080 / 0961321042000323815$

[14] Kärnä, S. Analysing customer satisfaction and quality in construction - the case of public and private customers. // Nordic Journal of Surveying and Real Estate Research. 2, (2004), pp. 67-80.

[15] Nzekwe-Excel, C. Satisfaction assessment in construction projects: a conceptual framework. // Built Environment Project and Asset Management. 2, 1(2012), pp. 86-102. DOI: $10.1108 / 20441241211235071$

[16] Li, T. H. Y.; Ng, T. S.; Skitmore, M. Evaluating stakeholder satisfaction during public participation in major infrastructure and construction projects: a fuzzy approach. // Automation in Construction. 29, (2013), pp. 123-135. DOI: 10.1016/j.autcon.2012.09.007

[17] Kärnä, S.; Junnonen, J. M.; Manninen, A. P.; Julin, P. Exploring project participants' satisfaction in the infrastructure projects. // Engineering Project Organization Journal. 3, 4(2013), pp. 186-197. DOI: $10.1080 / 21573727.2013 .823083$

[18] Ala-Risku, T.; Kärkkäinen, M. Material delivery problems in construction projects: A possible solution. // International Journal of Production Economics. 104, 1(2006), pp. 19-29. DOI: 10.1016/j.ijpe.2004.12.027

[19] Sobotka, A.; Czarnigowska, A.; Stefaniak, K. Logistics of construction projects. // Foundations of Civil and Environmental Engineering. 6, (2005), pp. 203-216.

[20] Agapiou, A.; Clausen, L. E.; Flanagan, R.; Norman, G.; Notman, D. The role of logistics in the materials flow control process. // Construction Management and Economics. 16, 2(1998), pp. 131-137. DOI: 10.1080/014461998372420

[21] Benton, W. C. Jr.; McHenry, L. F. Construction purchasing $\&$ supply chain management. New York: McGrow-Hill, 2010

[22] Korytárová, J.; Hromádka, V. Building life cycle economic impacts.// International Conference on Management and Service Science, MASS, Wuhan, China, 2010.

[23] Ren, Z.; Anumba, C. J.; Tah, J. RFID-facilitated construction materials management (RFID-CMM) - A case study of water-supply project. // Advanced Engineering Informatics. 25, 2(2011), pp. 198-207. DOI: 10.1016/j.aei.2010.02.002

[24] Macurová, P.; Jurásková, K. Analysis of risks generated by suppliers during the period of economic fluctuations. // Amfiteatru Economic. 15, 33(2013), pp. 27-43.

[25] Kärnä, S.; Junnonen, J. M.; Kankainen, J. Customer satisfaction in Construction. // Proceedings of the $12^{\text {th }}$ Annual Conference on Lean Construction, Helsinger, Denmark, 2004, pp. 476-488.

[26] Gunasekaran, A.; Ngai, E. W. T. Information systems in supply chain integration and management. // European Journal of Operational Research. 159, (2004), pp. 269-295. DOI: 10.1016/j.ejor.2003.08.016

[27] Kasim, N. ICT implementation for materials management in construction projects: case studies. // Journal of 
Construction Engineering and Project Management. 1, 1(2011), pp. 31-36. DOI: 10.6106/JCEPM.2011.1.1.031

\section{Authors' addresses}

Biljana Blaževska - Stoilkovska, PhD, Assistant Professor, Institute of Psychology, Faculty of Philosophy,

Ss. Cyril and Methodius University,

Blv. Goce Delčev 9A, 1000 Skopje, Republic of Macedonia

E-mail: biljanabs@yahoo.com

Tomáš Hanák, PhD, Assistant Professor,

Faculty of Civil Engineering, Brno University of Technology,

Veveři 95, 60200 Brno, Czech Republic,

E-mail: hanak.t@fce.vutbr.cz

Valentina Žileska - Pančovska, PhD, Full Professor,

Faculty of Civil Engineering, Ss. Cyril and Methodius University,

Blv. Partizanski odredi 24, 1000 Skopje, Republic of Macedonia

E-mail: valentinazp@gf.ukim.edu.mk 